\title{
Ethnic Crossing Politics as a Political Strategy for the Winning Candidate Pair Radiapoh Hasiholan Sinaga \& Zonny Waldi in the 2020 Simalungun Regent Election
}

\author{
Windawati Pinem \\ Pancasila and Citizenship Education Study Program Medan State University, Willem Iskandar Street \\ No.259, Medan, Indonesia \\ Corresponding Author: Windawati Pinem, Email: windapinem4@gmail.com
}

History: Received 30/12/2021 | Revised 03/01/2022 | Accepted 16/01/2022 | Published 31/01/2022

\begin{abstract}
This study aims to examine the political strategies used by Radiapoh Hasiholan Sinaga and Zonny Waldi in the election of candidates for the regent of Simalungun Regency in 2020. After the simultaneous and direct elections were held, political dynamics at the local level are still inseparable from ethnicity, religion, and kinship issues. This is what makes political competition in the region more heated. Therefore, a political strategy is needed, essential for political marketing. Radiapoh-Zonny's victory was inseparable from the political strategy used. Political strategy is formed from crucial issues in the Simalungun community, such as the plurality of tribes, religions, and groups. From these problems, a cross-ethnic political strategy was formed. Cross-ethnic politics is the election and incorporation of Simalungun regent candidates from various ethnic groups, religions, and races in the Simalungun Regency. The research method used is qualitative with literature study. Data collection techniques are carried out by collecting various literature such as research results, books, and journals. Data analysis was carried out using the triangulation method. This study shows that the issue of ethnicity has been successfully used as a political strategy not to divide society but rather as a political marketing strategy to attract voters' attention.
\end{abstract}

Keywords: Cross-Ethnic Politics, Winning Strategy, Simalungun Regent Election 2020

\begin{abstract}
Abstrak. Penelitian ini bertujuan untuk melihat strategi politik yang digunakan oleh Radiapoh Hasiholan Sinaga dan Zonny Waldi dalam pemilihan calon Bupati Kabupaten Simalungun tahun 2020. Pasca dilaksanakannya pilkada serentak dan langsung, dinamika politik di tingkat lokal masih belum terlepas dari persoalan etnisitas, keagamaan serta kekerabatan. Hal inilah yang menjadikan kompetisi politik di daerah semakin memanas. Oleh karena itu dibutuhkanlah sebuah strategi politik yang merupakan bagian penting dalam marketing politik. Kemenangan Radiapoh-Zonny tidak terlepas dari strategi politik yang digunakan. Strategi politik dibentuk dari isu-isu krusial yang ada dalam masyarakat Simalungun seperti kemajemukan suku, agama dan golongan. Dari persoalan tersebutlah strategi politik silang etnis terbentuk. Politik silang etnis adalah pemilihan dan penggabungan calon bupati Simalungun yang berasal dari berbagai suku, agama, dan ras yang ada di Kabupaten Simalungun. Adapun metode penelitian yang digunakan adalah kualitatif dengan studi pustaka. Teknik pengumpulan data dilakukan dengan mengumpulkan berbagai literatur seperti hasil penelitian, buku dan jurnal. Analisis data dilakukan dengan metode triangulasi. Adapun hasil dari penelitian ini bahwa isu etnisitas berhasil digunakan sebagai strategi politik bukan untuk memecah belah masyarakat, melainkan sebuah political marketing untuk menarik perhatian pemilih.
\end{abstract}

Kata kunci: Politik Silang Etnis, Strategi Politik, Pilkada Simalungun Tahun 2020 


\section{INTRODUCTION}

This study wants to see the cross-ethnic political strategy used by the Radiapoh-Zonny pair in the election of the Regent in Simalungun Regency in 2020. This research provides a different space on the issue of ethnicity in Indonesia. So far, the issue of ethnicity has always been an issue that is alleged to be dividing society. This departs from the diversity of tribes, religions, races, and groups in Indonesia, which is why the issue of ethnicity is so sensitive to be discussed. However, in this study, the issue of ethnicity is not used as a political tool to gain power. Instead, ethnicity is used as political marketing for contestants to attract voters' attention. This is what makes this research interesting to study because it has differences from previous research.

Since the collapse of the New Order in 1998, strengthening local democracy has become one of the essential conditions for the reform process to run. But unfortunately, the local democracy that was built after the New Order gave birth to the mobilization of ethnic forces, kinship, and religious sentiments. So that in every election, both the Regent and Governor to the Village Head still consider ethnic and religious representation, to powersharing between dominant ethnic groups. (Manan, 2004).

Strengthening the quality of local democracy makes political competition getting hotter. Every political candidate must be able to compete fiercely for voter support. The increasingly fierce competition is certainly inseparable from the journey of post-reform local democracy. Local democracy is still characterized by the control of certain elites over democratic institutions making the democratic process elitist (Democracy and Human Rights Study Institute (DEMOS), 2005). The old predatory elite based on political parties still dominates the political scene (Robison \& Hadiz, 2004). This means that the development of democracy after the collapse of the New Order did not eliminate the power of the old elites (Schulte Nordholt \& van Klinken, 2014). Through electoral democracy, the old elites built alliances with the local middle class with a patronal character, which was ethnic-based (Suwignyo, 2015).

One of the studies that Mukmin, BA and Damanik have carried out on Political Demography of North Sumatra: Analysis of Community Political Choices Based on Population Distribution, Religion, and Ethnicity in the 2018 North Sumatra Governor Election shows that North Sumatra is one of the regions with population distribution based on similarity in religion, ethnicity, and origin. Regional proposal. This impacts the political choices of the people of North Sumatra. Especially in the 2018 North Sumatra gubernatorial election, where the issue of ethnicity and the sons of the region became a 
vote-getter to gain power (Mukmin \& Damanik, 2018).

This is in line with the research conducted by Ahmad J. In this study, it was found that the reformation had changed the political system in Indonesia. These changes impact political shifts from the central government to the regions, giving birth to ethnic sentiments. This also happened in Jambi, which provided space for the issue of ethnicity to emerge and develop (Ahmad, 2015).

Therefore, to improve the quality of local democracy in Indonesia, the government issued Law No. 22 of 1999 concerning Regional Government. This is further strengthened by Law No. 32 of 2004, which replaces Law No. 22 of 1999 (Romli, 2018). The people directly elect regional heads (regents, mayors, and governors) based on the new law. This replaces the role of DPRD, which has been responsible for selecting regional leaders. The law is considered a solution to problems that arise in the postreform area.

After the law was passed, in 2015, the local elections began to be carried out directly and simultaneously. Simultaneous "transitional" elections have begun to be piloted. At that time, not all regions did it. There were only about 224 regencies and 36 cities in Indonesia. There are several reasons why the people must conduct the elections directly. First, this is to break the oligarchy, challenging to eliminate in the local political dimension. Second, with direct local elections, the quality of public participation will improve. Third, the direct election will make the selection process bottom-up. After that, simultaneous local elections were held to minimize the costs incurred. So that the state can save money by holding simultaneous regional elections (Romli, 2018), however, the law could not answer all the problems that exist in the region, including the issue of ethnic politics. Ethnicity politics remains a hot issue in the areas, especially before the regional head elections and village head elections.

\section{RESEARCH METHODS}

Research is an essential part of the development of science. Research places the most urgent position in science, to develop it and protect it from extinction (Bungin, 2011). Researchers can recognize the subject, feel what the subject feels in everyday life. Qualitative research will involve researchers to understand the setting of the phenomenon being studied (Basrowi \& Suwandi, 2009). This research used a qualitative method with a literature study. Sources of data come from primary and secondary data. Preliminary data were researchers who analyze answering research questions, while secondary data were books, journals, and relevant research results. The data collection method was carried out from various literature such as books, journals, and relevant research. Data analysis was done 
by the triangulation method. Triangulation is done by comparing the data that has been obtained (Sugiono, 2012).

\section{DISCUSSION}

Simalungun Regency is one of 33 regencies/cities in North Sumatra. This district consists of 31 sub-districts, 310 villages (nagori) and 21 sub-districts. Demographically, Simalungun Regency is located on the shores of Lake Toba with fertile soil conditions. Local residents take advantage of the fertile natural conditions by farming. So that the majority of the population in Simalungun Regency are farmers. The rest of the people work as civil servants, entrepreneurs, raising livestock, etc. Administratively, Simalungun Regency is located in North Sumatra Province, which is precisely in the middle of the province. Geographically, it is located between the coordinates of $2036^{\prime}-3018^{\prime}$ North Latitude and $98032^{\prime}$ - 990 35' East Longitude. Administratively, Simalungun Regency is bordered by: To the north. It is bordered by Serdang Bedagai/Deli Serdang. In the west it is bordered by Karo. In the east, it is bordered by Asahan/Batu Bara Regency. It is bordered by Toba Samosir Regency and Samosir Regency to the south.

Simalungun Regency is also one of the areas with a high level of community pluralism. This plurality is seen from the variety of ethnicities, religions, and groups that inhabit this region. The tribes who live here are the Simalungun Batak, Pakpak Batak, Karo Batak, Malay, Minangkabau, Sundanese, Chinese, and Javanese, who are immigrants and are the most numerous in this region. In terms of religion, Islam is the most common religion in this area. Then there are Christians, Protestants, Catholics, Buddhists, and Hindus. All spread in various areas in Simalungun district. This plurality is often used as a political tool in an election. Especially since the decentralization policy initiated by the government began to be moved. Regions seem to lose control in managing their local democracy. The issue of ethnicity stands tall and is difficult to shake. This makes the political competition more challenging.

The regional head election of Simalungun Regency in 2015 was followed by a candidate pair who stumbled upon a legal case but eventually succeeded in participating in the regional head election. The character is JR Saragih. The 2015 regional head elections had to be postponed due to legal issues involving JR Saragih and Amran Sinaga. The two pairs of candidates for Regent were removed from the Simalungun KPU. However, the Supreme Court decided that the pair could participate in the regional head election in the end. This pair also won the 2016 Simalungun regional head election (Pasaribu, 2017).

This figure is identical to Simalungun Regency. The power and power of JR Saragih 
seem challenging to eliminate in the political arena in Simalungun (Situmorang et al., 2020). In addition, the strong support from the Democratic party as the major party in Simalungun adds to the strong dominance. But unfortunately, the dominance and power of JR Saragih could not continue. In the 2020 regional head election, JR Saragih can no longer run as a candidate for Regent.

JR Saragih's political domination power does not stop there (Situmorang et al., 2020). Through his brother, it seems that he wants to continue his brother's power in the 2020 Simalungun regional head election. Anton Achmad Saragih paired with Rospita Sitorus in the last serial number (4), which PAN, PDIP, and Nasdem support. The 2020 Simalungun regional head election consists of four political pairs. The serial number 1 candidate pair Radiapoh Hasiholan Sinaga - Zonny Waldi is a pair that comes from businessmen and bureaucrats. They were promoted by Perindo, Golkar, Hanura, PKS, and the Berkarya Party. Candidate number 2, Muhajidin Nur HasimTumpak Siregar, is supported by the Democratic Party and Gerindra. Candidate number 3 is Maruli Wagner DamanikAbidinsyah Saragih, a non-party/independent fighter. Lastly, candidate pair number 4, Anton Achmad Saragih - Rospita Sitorus, is supported by PDIP, PAN, and Nasdem.

Apart from the political power of one of the figures in Simalungun, the political dynamics in the Simalungun regional head election cannot be separated from the issue of ethnicity. When viewed ethnographically, this area does have a high level of community pluralism. This is marked by various ethnic groups, religions, races, and groups. The original tribe that inhabits Simalungun is the Simalungun Batak tribe. This tribe is known to be very thick with customs and customs. In addition to these tribes, there are also other tribes such as the Pakpak Batak, Karo Batak, Javanese, Minang, Sundanese, Chinese, and Malay. Although North Sumatra is famous for its heterogeneous society, there is no dominant culture (Bruner, 1961). It is known that about 15 ethnic groups are living in North Sumatra, but none of them dominate. Likewise, in religion, the majority of Muslims, but no one dominates. This makes it easier for society to be polarized based on ethnicity segments (Williams et al., 1964). Ethnicity is used to fight for power and interests that a group of people deliberately carries out. So that in the phenomenon of the development of democracy in North Sumatra, religion and ethnicity become the most important part in identity politics.

This is reinforced by Erond L Damanik's research on ethnic politics at the local level in 2018. Where the decentralization and regional autonomy agendas turned out to display a democratization process that went too far. In the end, the policy of decentralization and regional autonomy gave birth to a dynamic of localization of power in the regions. This 
localization is related to the issue of ethnicity, which is not only interpreted as a matter of primordialism but also about political tools. North Sumatra is one area that feels the impact of this localization. Elections for governors, regents, and village heads always involve ethnic issues (Damanik, 2018). So that reform is often seen as the cause of strengthening ethnicity politics at the local level.

The same thing is also found in the book on "Primordialism politics in elections in Indonesia." In the book, it is found that the political presence of primordialism is inevitable as a product of decentralization. The result of this policy is that the phenomenon of ethnicity, regionalism, the sultanate is included in the political realm (Habbodidn, 2015).

This is the opposite in the early days of independence. The issue of ethnicity is not popular in politics. in the book entitled "Religion and Ethnicity as Political Issues," it is explained that in the 1955 elections, political parties that used ethnic identity issues did not win. As a Muslim-majority country, the election's winner did not come from an Islamic party. One reason is that the spirit of anticolonialism is more popular than ethnicity (Widyawati, 2014). Based on the various references described above, a fundamental difference was found with this study. Ethnicity does not always have a negative meaning but can be used as a political strategy of a political nature. This certainly provides a new discourse in the field of political science that can be distinguished from other works. The issue of ethnicity has indeed grown and developed from time to time. However, it reached its peak of glory when the reforms rolled. After the reform, the issue of ethnicity has not been resolved but has grown stronger. The decentralization policy has provided space for local elites to assert their power. It is undeniable that decentralization fosters intense competition in local political contestations. So that every political contestant who will advance in a democratic party must have a political strategy that is right on target. Especially considering the number of political parties currently, political marketing is an important part.

\section{Simalungun Regional Head Election In 2020}

At the beginning of the establishment of Simalungun Regency, the capital city was Pematang Siantar. However, after Pematang Siantar became an autonomous region, the capital city of Simalungun Regency became Pematang Raya. Simalungun Regency was formerly known as the base of the Golkar Party. However, the power of the Golkar party began to shift with the presence of the Democratic party in Simalungun. Moreover, when JR Saragih became the Regent of Simalungun, the Democratic party managed to be at the peak of its glory. But along with the fall of JR Saragih's power, the strength of the 
Democratic party began to weaken. This can be seen from the victory of the candidate pair promoted by the Golkar party again, namely Radiapoh-Zonny.

The political dynamics in this area are also not far from the issue of ethnicity. Ethnicity is often political bait in winning political contestations. This is what makes power interplay and the competition more challenging. So it takes a political strategy to conquer the hearts of the people.

The election for the regional head of Simalungun Regency will take place on December 9, 2020. Four pairs of candidates have registered as candidates for Regent. The following is a list of candidate pairs and their supporting political parties.

1. Radiapoh Hasiholan Sinaga- Zonny Waldi.

Radiapoh is an entrepreneur, while Zonny is the Head of Industry \& Trade of North Sumatra Province. Six political parties support this candidate pair. Starting from Golkar, Perindo, PKS, Berkarya, Hanura and PPP. Radiapoh is the original son of Simalungun, while Zonny is from Fifty Cities District.

2. Muhajidin Nur Hasim - Tumpak Siregar. Muhajidin also works as a businessman. Two political parties promoted this candidate pair, Democrat and Gerindra. During the reign of JR Saragih, the Democrat party was the political party that succeeded in overthrowing the power of Golkar. However, the image of the
Democratic party began to decline with the fall of JR Saragih.

3. Maruli Wagner Damanik - Abidinsyah Saragih. Maruli is an expert staff member of the Indonesian National Defense and Security Agency. At the same time, the representative is a businessman. This candidate pair advanced as an independent candidate. After the existence of Law No. 32 of 2004, participants in the regional head election may come from non-party (independent) parties.

4. Anton Achmad Saragih - Rospita Sitorus. Anton is the brother of JR Saragih, who is also the chairman of the Simalungun Islamic Family Association (IKEIS). While the deputy is a member of the Simalungun DPRD for the 2019-2024 period. PDIP, Nasdem, and PAN promoted this candidate pair. There are exciting things here when viewed from the supporting political parties. Anton, the brother of incumbent JR Saragih, was not encouraged by the Democrat party. The Democrat Party is the party raised by his younger brother JR Saragih in Simalungun and succeeded in bringing him to power.

The 2020 regional head election is not much different from the previous regional head election. The various dynamics that surround it do not have significant differences. Starting from the issue of ethnicity, religion, and class, it seems that they always appear in every regional head election. Only this time, 
the figure of JR Saragih, who usually became a contestant, was replaced with the figure of his brother. The enthusiasm of the community is also no less excited. This is because the community can vote for their regional head candidate. The direct election of regional heads has given the people the authority to determine directly who deserves to be their leader. Direct elections have several weaknesses, such as allegations of money politics, horizontal conflicts, and high costs. However, there are several reasons why direct regional head elections are good to carry out (Romli, 2018). First, if the DPRD elects the regional head, it will be oligarchic and elitist. Second, the elected regional heads are not necessarily in accordance with the people's wishes. Third, if the DPRD elects the regional head, then the elected regional head will depend on the DPRD, not the people. Therefore, the direct regional head election has a special place in the hearts of the people

The democratic party in Simalungun also reached its peak. The heated political situation increased the people's enthusiasm to come to the polling stations to cast their votes. The various conflicts did not dampen the community's intention to find a trustworthy leader. So that in the end the election of the candidate for Regent of Simalungun Regency in 2020 was won by Candidate 1, namely Radipaoh - Zonny. Paslon 1 won with 194,163 votes. The Radiapoh - Zonny Paslon excel in several areas such as Bandar Subdistrict,
Bandar Haluan, Bandar Masilam, Dolok Masagal, Dolok Panribuan, Dolok Pardamean, Dolok Batu Nanggar and Girsang Sipangan Bolon District. Districts of Gunung Melala, Mount Maligas, Haranggaol Horison, Huta Bayu Raja, Jawa Maraja Bah Jambi, Pematang Silima Huta, Panei, Pematang Bandar and Purba Districts. The next highest number of votes was followed by candidate pair 4, namely Anton - Rospita, with 127,608 votes. The results of this voting decision were obtained based on the Simalungun KPU No. 175/PL.02.6-Kpt/1208/KPU-Kab/XII/2020.

During the Radiapoh - Zonny candidate pair campaign, Zonny was very aggressive in voicing development ideas in Simalungun. Developments that previous leaders have carried out for the past ten years are considered unable to embrace the community's interests. Therefore, the Radiapoh-Zonny candidate pair tried to improve development in Simalungun. This candidate pair will later involve many actors involved in each policy, including residents of Javanese descent in Simalungun. One of the policies that will be issued in development is the idea of Simalungun Kerja (The Work). The hope is that the unemployment rate in Simalungun can be overcome.

In addition, the victory of the RadiapohZonny pair was due to the political strategy used. This pair also received political support from an ethnic group in Simalungun which added to its political power. The association is 
part of the Nusantara Communication Forum for Javanese Citizens (FKWJ). Through the chairman of FKWJ Nusantara-Simalungun $\mathrm{H}$ Ngatijan Toha has entrusted Simalungun Regency in the hands of Radiapoh-Zonny. This is because, according to him, this candidate pair has eight leadership attitudes that exist in Javanese figures, namely Pandu. This leadership attitude is known as Hasta Brata. Through this belief, the RadiapohZonny candidate pair is considered capable of bringing about change in Simalungun Regency. Political support from one of the Javanese community associations has mobilized its citizens in 21 sub-districts spread across Simalungun Regency. Political support from one of the social associations in the name of ethnicity does have a significant influence. It is especially considering that the Javanese people in Simalungun are scattered in almost all areas. Of course, this became a magnet for Candidate 1 to gain the sympathy of the Javanese people, and it was proven that Candidate 1 won in areas where the majority were ethnically Javanese.

Empirically, ethnicity is still an attraction in every political event. Even the issue of ethnicity is often used as a political tool to gain profit. Especially considering that North Sumatra is famous for its heterogeneous society, even though there is no dominant culture (Bruner, 1961). It is known that about 15 ethnic groups are living in North Sumatra, but none of them dominate. Likewise, in religion, the majority of Muslims, but no one dominates. This makes it easier for society to be polarized based on ethnicity segments (Williams et al., 1964). Ethnicity is used to fight for power and interests that a group of people deliberately carries out. So that in the phenomenon of the development of democracy in North Sumatra, religion and ethnicity become the most critical part of identity politics.

\section{Ethnic Cross Politics as a Political Strategy}

As is well known, political strategy is a technique used to realize political ideals (Schroder, 2009). Political strategy is part of marketing politics. The purpose of political strategy is to win the battle in increasingly fierce competition. By using the right target strategy, it will be easier to map the targets to be achieved.

In the Simalungun regional head election, the victory of the Radiapoh-Zonny candidate pair was also inseparable from the political strategy used. The political strategy used is cross-ethnic politics. Based on its name, ethnicity is used as a "political tool" to attract the attention of voters. The targets are the indigenous Simalungun ethnic community and the immigrant ethnic community. In this case, ethnicity is used as a political tool in a negative sense. a positive step in two different ethnicities. Actually to determine a political strategy can use the issues that develop in society. Including the issue of ethnicity and 
religion. It's just that often the issue of ethnicity and religion is used as a divider in society. However, the political strategy of using ethnicity as used by the Radiapoh-Zonny candidate pair was originally to divide society. a first step in determining the pair seen from the tribe. As is well known, Radiapoh is a native of Simalungun with the Sinaga clan. Meanwhile, Zonny is an immigrant from West Sumatra and has a career in North Sumatra. This condition was used by the success team to conduct cross-ethnic activities as an effort to gain voice support. Especially from the original Simalungun ethnic and ethnic immigrants. As a result, it turned out that this strategy was able to bring the candidate pair to win as regent $\&$ deputy regent of Simalungun in 2020 .

The political steps taken by the Radiapoh-Zonny success team were sorting out the elements of political marketing. There are several elements of marketing politics needed to determine strategy.

\section{Ethnic Cross Politics as a Political Strategy}

As is well known, political strategy is a technique used to realize political ideals (Schroder, 2009). Political strategy is part of marketing politics. The purpose of political strategy is to win the battle in increasingly fierce competition. Using the right target strategy will make it easier to map the targets to be achieved.
In the Simalungun regional head election, the victory of the Radiapoh-Zonny candidate pair was also inseparable from the political strategy used. The political strategy used is cross-ethnic politics. Based on its name, ethnicity is used as a "political tool" to attract voters' attention. The targets are the indigenous Simalungun ethnic community and the immigrant ethnic community. In this case, ethnicity is used as a political tool negatively. A positive step in two different ethnicities. Determining a political strategy can use the issues that develop in society, including the issue of ethnicity and religion. It's just that often, ethnicity and religion are used as a divider in society. However, the political strategy of using ethnicity by the RadiapohZonny candidate pair was originally to divide society. A first step in determining the pair seen from the tribe. As is well known, Radiapoh is a native of Simalungun with the Sinaga clan.

Meanwhile, Zonny is an immigrant from West Sumatra and has a career in North Sumatra. The success team used this condition to conduct cross-ethnic activities to gain voice support, especially from the original Simalungun ethnic and ethnic immigrants. As a result, it turned out that this strategy was able to bring the candidate pair to win as regent \& deputy regent of Simalungun in 2020.

The political steps taken by the Radiapoh-Zonny success team were sorting out the elements of political marketing. There 
are several elements of marketing politics needed to determine strategy.

Figure 1: Elements of Political Marketing

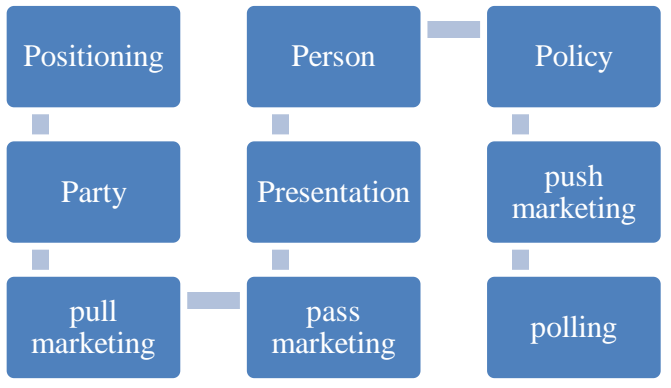

Source: (Nursal, 2004)

Based on the figure, it can be seen that there are nine essential elements in building a political strategy. Starting from positioning to polling. These elements serve as guidelines for successful teams to make strategies that are right on target. The initial step can be done by selecting a candidate that fits the voter criteria. Based on these elements, Radiapoh and its success team have succeeded in mapping out the targets to be achieved. The ethnic diversity in Simalungun is used as a political strategy that is considered appropriate to attract voter support.

Positioning is a communication strategy to enter the voter's mind so that the contestant has more value in the eyes of the voter. For positioning to work well, it must display the advantages of the contestants in front of the voters. In addition to showing the benefits of the contestants, making offers in political products sold will make voters more confident. Political developments can be in policy, person, party, and presentation. The policy is an offer of a policy/work program. A person is a political candidate who will compete in the regional head election. The party is a political party that carries and supports it, and the presentation offers the three products to voters. Political products provided must be different from other contestants. A distinctive, precise, and meaningful position will attract voters.

Figure 2:Political Products

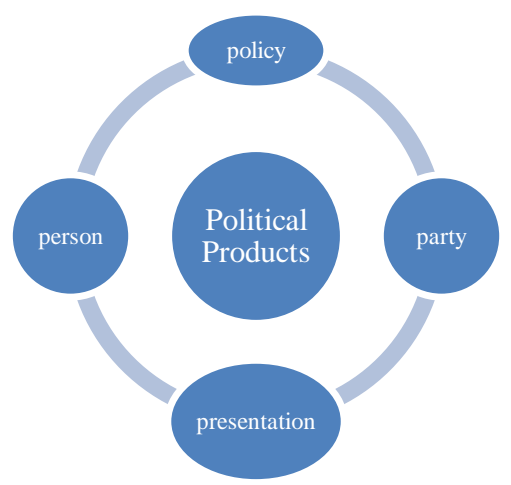

Source: (Farazian \& Paskarina, 2021)

Positioning can be done by defining core values. Core values can be developed from the identity of class, religion, ethnicity, or social group (Butler P \& Collins A, 1996). It is these values that can be binding and are called positioning. This step is important in shaping the image of the contestants in the eyes of voters. The Radiapoh Paslon started this step by selecting a duet with Radiapoh, namely Zonny. The positioning that is built is by cross-ethnicity. This step is considered appropriate to get support from various ethnic groups in Simalungun.

A person is a political candidate who will advance in political contestation. The figure of this figure is very influential on voter behavior. Showing a figure who is liked by the community will be the first step in forming a 
political image. Usually, the prospective candidate will first develop his branding to look attractive in the community. If viewed from this section, the Radiapoh-Zonny candidate pair is a figure that was formed with its simplicity. An understated, populist and authoritative appearance is one part of personal branding. Several dimensions affect the quality of candidates. The following can be seen from the image presented.

Figure 3 Dimensions of Candidate Quality

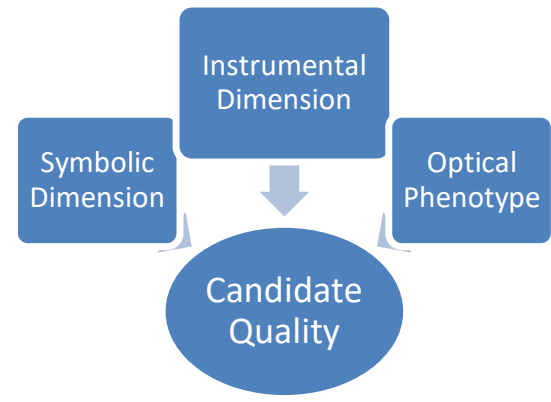

Source: (Widiowati \& Pramutanto, 2021)

Instrumental dimensions include managerial competence and functional competence. The symbolic dimension includes basic principles, emotional, inspirational, and social aura. At the same time, the optical phenotype includes physical charm, health, and appearance. These are the things that have been formed from the Radiapoh-Zonny candidate pair to prepare for the 2020 Simalungun regional head election.

Party is a political party that supports the candidate. The party plays a vital role as a political machine. The goal is to gain and control power. The party will win the sympathy of the voters by offering people and policies as expected by the voters. The return of the strength of the Golkar party in Simalungun by supporting the RadiapohZonny candidate pair became one of the political attractions. As is well known, the Golkar party was once removed from the political power scene in Simalungun when JR Saragih was in power. However, the Radiapoh-Zonny candidate pair has brought back the glory of the Golkar party in Simalungun.

The policy is a policy/program that is offered to voters. The policy is considered a solution to various problems in society. The policy can be in education, economy, society, culture, and politics. The policies offered usually involve various problems faced by voters.

Presentation is a way of delivering political products that will be sold to voters. In politics, candidates are sellers while voters are consumers. Therefore, the seller must be careful in winning the hearts of potential buyers of his political products. Delivering information about the products offered is the key to success in political contestation.

Push marketing is an effort so that political products can touch the hearts of voters directly (Shea, D.M \& Burton, 2001). The advantage is that it can direct voters to a different cognitive level than other campaigning forms.

Pull marketing is a way of using media. You can pay or without paying. This approach 
determines the image formation of a contestant.

Pass marketing involves active and passive influencers to influence voters. Passive influencers are individuals or groups who do not actively influence voters but become voters' referrals. For example, celebrities. Active influencers are individuals or groups who are actively involved in influencing voters.

Polling is to measure the effectiveness of the various elements described above. Polling is the final step to determine the extent to which people are interested in the products offered. Usually, the poll will involve a survey agency to collect data in the field.

After taking these steps, the candidate pair and their successful team will find it easier to find their market share. Moreover, the strategy used is the issue of ethnicity, so it takes proper political marketing so as not to backfire for the candidate pair and voters. Understanding the politics of ethnicity in Indonesia can be guided by Nordholt's thoughts, which concludes that ethnicity politics is part of identity politics that has been formed since the New Order era (Nordholt, 2012) so that the politics of ethnicity is a creation of the state to label its citizens. It aims to control the state's politics over its citizens. In fact, during the New Order, several policies were made by the government to suppress the pace of ethnic politics. First, there is no original area, meaning that all areas are open to separate all communities from their sociocultural and political roots. Second, the government avoids the formation of classes, and the issue of SARA is closely monitored. Third, carry out modernization so that the influence of ethnicity and religion decreases. Fourth, the important role of the state in regulating so that there is no overlap between religion and ethnicity. So that the existence of these policies will have a political impact on the regulatory relationship between the center and the regions. So that religion and ethnicity are no longer a place to express themselves politically.

However, after the reformation began, the issue of ethnicity seemed to be unable to disappear. Even at the regional level, this issue also develops along with various policies made by the government. Often, ethnicity is used as a form of association to gain economic and political interests (Barker, 2004). So that ethnicity is no longer considered as an ethnic group that is doing affirmations. However, ethnicity is used to pursue political interests. The use of ethnicity as a political tool is not always considered wrong. Even the use of ethnicity issues as a political strategy to attract support from the community is deemed to be normal. This will not harm the local democracy that we want to build. No one is harmed in this case, so it can strengthen the quality of local democracy. 


\section{CONCLUSION}

Simalungun Regency is an area with a high level of ethnic pluralism. The diversity of ethnicities in Simalungun turned out to be used as a political strategy for Radiapoh-Zonny in winning the Simalungun regional head election. The victory of the Radiapoh-Zonny candidate pair in the 2020 Simalungun regional head election is inseparable from the political strategy used. The political strategy used is cross-ethnic politics. Cross-ethnic politics is a technique for selecting candidates based on ethnicity/ethnicity. The RadiapohZonny candidate pair is a political candidate from the Simalungun ethnic group (Radiapoh Sinaga) while Zonny is from West Sumatra. This cross-ethnic blend aims to attract the sympathy of the indigenous Simalungun community and the immigrant community, who comprise the largest population in Simalungun. This strategy is an important part of political marketing to offer political products to voters. The result is that RadiapohZonny succeeded in winning the Simalungun Regency Regent election in 2020. The issue of ethnicity was not used as a divider in society but as a marketing strategy to attract voters' sympathy.

\section{REFERENCES}

[1] Ahmad, J. (2015). Demokrasi Dan Etnisitas: Studi Politisasi Kelompok Etnik Pada Pemilihan Walikota/ Wakil Walikota Jambi Tahun 2013. Al-Qisthu: Jurnal Kajian IlmuIlmu Hukum. https://doi.org/10.32694/010300

[2] Barker. (2004). Ethnicity and Nationalisme.
Pluto Press.

[3] Basrowi \& Suwandi. (2009). Memahami Penelitian Kualitatif. PT Rineka Cipta.

[4] Bruner, E. M. (1961). Urbanization and Ethnic Identity in North Sumatra. American Anthropologist. https://doi.org/10.1525/aa.1961.63.3.02a000 40

[5] Bungin, B. (2011). Metodologi Penelitian Kualitatif. In Rineka Cipta.

[6] Butler P \& Collins A. (1996). A Conceptual Framework of Political Marketing. Sage Publication.

[7] Damanik, E. L. (2018). Dinamika Etnisitas pada Era Desentralisasi di Sumatera Utara. Simetri Institue.

[8] Farazian, T. A., \& Paskarina, C. (2021). Political marketing in the 2019 local election: A case of the Indonesia solidarity party in the legislative election in Jakarta. Academic Journal of Interdisciplinary Studies. https://doi.org/10.36941/ajis-2021-0119

[9] Habbodidn, M. (2015). Politik Primordialisme Dalam Pemilu di Indonesia. UB Press.

[10] Lembaga Kajian Demokrasi dan HAM (DEMOS). (2005). Menjadikan Demokrasi Bermakna : Masalah \& Pilihan di Indonesia. DEMOS.

[11] Manan, B. (2004). Menyongsong Fajar Otonomi Daerah. FH UII.

[12] Mukmin, B. A., \& Damanik, M. R. S. (2018). Demografi Politik Sumatera Utara: Analisis Pilihan Politik Masyarakat Berdasarkan Persebaran Penduduk, Agama dan Etnis Dalam Pemilihan Gubernur Sumatera Utara Tahun 2018 di Kota Medan. JURNAL GEOGRAFI.

https://doi.org/10.24114/jg.v10i2.10532

[13] Nordholt, H. S. (2012). Decentralization and democracy in Indonesia: Strengthening citizenship or regional elites? In Routledge Handbook of Southeast Asian Politics. https://doi.org/10.4324/9780203155011-26

[14] Nursal, A. (2004). Political Marketing, 
Strategi Memenangkan Pemilu, Sebuah Pendekatan Baru Kampanye Pemilihan DPR, DPD, Presiden. PT Gramedia.

[15] Pasaribu, I. (2017). PILKADA SERENTAK DAN HUKUM POLITIK: KONTROVERSI KEBIJAKAN PEMERINTAH PUSAT TERKAIT PUTUSAN HUKUM PILKADA KABUPATEN, SIMALUNGUN SUMATERA UTARA TAHUN 2015. Politika: Jurnal Ilmu Politik. https://doi.org/10.14710/politika.8.1.2017.8 2-91

[16] Robison, R., \& Hadiz, V. R. (2004). Reorganising power in Indonesia: The politics of oligarchy in an age of markets. In Reorganising Power in Indonesia: The Politics of Oligarchy in an Age of Markets. https://doi.org/10.4324/9780203401453

[17] Romli, L. (2018). Pilkada Langsung, Calon Tunggal, dan Masa Depan Demokrasi Lokal. Jurnal Penelitian Politik. https://doi.org/10.14203/jpp.v15i2.757

[18] Schroder, P. (2009). Strategi Politik. FNS.

[19] Schulte Nordholt, H. G. C., \& van Klinken, G. (2014). M. Isa Sulaiman (1951-2004). In Renegotiating Boundaries. https://doi.org/10.1163/9789004260436_003

[20] Shea, D.M \& Burton, M. . (2001). Campaign Craft: The Strategies, Tacties, and Art of Political Campaign Managemant. Preager.

[21] Situmorang, T. P., Saragih, A., \& Pasaribu, I. (2020). Violations and Administrative Disputes Completion in the Local Election: A Case Study of Crossing a Candidate Pair of JR Saragih-Ance Selian Candidates in 2018 North Sumatra Election. https://doi.org/10.5220/0010012301060111

[22] Sugiono. (2012). Metode Penelitian Kualitatif Sugiyono. Mode Penelitian Kualitatif.

[23] Suwignyo, A. (2015). Gerry van Klinken and Ward Berenschot, eds. 『In Search of Middle Indonesia: Middle Classes in Provincial Towns Leiden: KITLV Press; Boston: Brill, 2014, xvi+242p. Southeast Asian Studies. https://doi.org/10.20495/seas.4.1_209
[24] Widiowati, B., \& Pramutanto, W. (2021). STRATEGI PEMENANGAN CALEG PARTAI GERINDRA DALAM PEMILU LEGISLATIF 2019: STUDI KASUS BAMBANG PUJIANTO DAPIL 2 SIDOARJO. Jurnal Politik Indonesia (Indonesian Journal of Politics). https://doi.org/10.20473/jpi.v6i2.30420

[25] Widyawati, N. (2014). Etnisitas dan Agama Sebagai Isu Politik. Yayasan Obor Indonesia.

[26] Williams, R. M., Glazer, N., \& Moynihan, D. P. (1964). Beyond the Melting Pot: The Negroes, Peurto Ricans, Jews, Italians, and Irish of New York City. American Sociological Review. 